\title{
EXPERIMENTAL STUDY ON STRENGTH CHARACTERISTICS OF CRUSHED-ROCK HIGH-POLYMER COMPOSITE POROUS MATERIALS
}

\author{
EKSPERIMENTALNA ŠTUDIJA TRDNOSTI POROZNIH \\ KOMPOZITNIH MATERIALOV IZ MEŠANICE ZDROBLJENEGA \\ KAMENJA IN VISOKEGA POLIMERA
}

\author{
Jian Zhang*, Yunfan Gu \\ School of Architectural Engineering, Nanjing Institute of Technology, Nanjing 211167, China \\ Prejem rokopisa - received: 2018-12-11; sprejem za objavo - accepted for publication: 2019-03-11
}

doi:10.17222/mit.2018.267

\begin{abstract}
In this experimental investigation, a new kind of composite material formed by mixing crushed rock with high polymer was analysed. It did not only retain the porous characteristics of crushed rock, but also enhanced its integrity. In view of the strength of the porous composite of crushed rock and high polymer, the influence of the material mixture ratio (high polymer:crushed rock) and particle size of crushed rock on the strength was analysed. The results showed that the strength of porous materials of crushed rock and high polymer mainly came from the oxidation and consolidation of high-polymer adhesives and mutual embedment between crushed-rock aggregates; the strength increased rapidly in the early stage and tended to be gradually stable in the later stage. The amount of adhesive, the particle size of crushed rock, the curing age and other factors had an impact on the strength; the amount of adhesive and the particle size of crushed rock had a particularly significant impact on it.

Keywords: crushed rock, high polymer, strength characteristics, porous composite
\end{abstract}

Avtor v eksperimentalni raziskavi analizira novo vrsto kompozitnega materiala, sestavljenega iz mešanice zdrobljenega kamenja (pretežno apnenca) in visokega polimera, ki ne samo da ohranja poroznost zdrobljenega kamenja, temveč tudi izboljšuje njegovo integriteto. Analiziral je trdnost tega kompozita glede na razmerje med količino polimera in zdrobljenega kamenja ter velikostjo njegovih delcev. Rezultati analiz kažejo, da je trdnost kompozita predvsem posledica oksidacije in konsolidacije polimernih lepil (veziv) in medsebojnega oplaščenja zdrobljenih agregatov skalovine, ki hitro narašča v zgodnjih stadijih in postaja stabilna v zadnjih stadijih izdelave kompozita. Vsebnost veziva, velikost zdrobljenega kamenja, čas utrjevanja in drug faktorji vplivajo na udarno trdnost kompozita. Pri tem na udarno trdnost izdelanega kompozita najbolj vplivata vsebnost veziva in velikost delcev zdrobljenega kamenja.

Ključne besede: zdrobljeno kamenje, visoki polimer, trdnostne karakteristike, porozni kompozit

\section{INTRODUCTION}

As one of the important facilities for slope protection, protective covering is the main application field for various new technologies, new materials and new processes in slope engineering. A composite material is formed by mixing ordinary engineering crushed rock with high polymer in a certain proportion. On the one hand, compared with concrete and other conventional impermeable surface-protection materials, the content of high polymer in crushed-rock high-polymer composites is small and the porous properties of crushed-rock materials are retained so that a composite porous protective covering of crushed-rock polymer is a kind of permeable protective covering. On the other hand, high polymer binds crushed-rock particles together well, enhancing the integrity of crushed-rock materials and making high-polymer composite materials highly erosion resistant. The protective covering formed is an erosion-resistant protective covering. Therefore, the

*Corresponding author's e-mail:

18626439990@163.com development of a composite porous anti-erosion protective covering of crushed-rock high polymers does not only solve the problem of insufficient water-erosion resistance of a natural-plant protective surface, but also makes up for the shortcomings of a traditional concrete protective surface structure, which is expensive and lacks naturalness. ${ }^{1-5}$

At present, there are few reports on the study of the composite porous anti-erosion protective covering technology using crushed rock and high polymer. ${ }^{6-10}$ The existing reports are limited to the study of the conventional crushed-rock protective covering. Zhong et al. ${ }^{11}$ and Verhagen ${ }^{12}$ carried out model tests on the stability of Elastocoast breakwaters under wave action. The results showed that the force acting on the protective covering was reduced by $20-58 \%$ due to the open pore structure. Liu et al. ${ }^{13}$ proposed a new embankment structure of a crushed-rock revetment and a slope thermal protection measure was designed. Soldinger et al. ${ }^{14}$ described a model to predict the transport velocity of a crushed-rock material bed along an ordinary screen with a circular stroke. Qian et al. ${ }^{15}$ investigated the characteristics 
caused by the temperature difference and observed that the temperature difference is a decisive factor for the occurrence of convection and its intensity. Chakrabarti et al. ${ }^{16}$ investigated the tensile-strain behavior of crushed rock stabilized with cementitious additives. They observed that the tensile strength and failure strain developed with the curing time. Borgesson et al. ${ }^{17}$ observed that the influence of heterogeneities in the soil structure of backfill materials made of mixtures of crushed rock and bentonite powder on the hydromechanical properties was very strong. Ma et al. ${ }^{18}$ investigated the impact of the diameter of various particles and axial displacement on the permeability of crushed rock. They found that the porosity decreased with an increase in the axial displacement and a decrease in the large-particle size.

In summary, as a kind of protective material, crushed-rock high-polymer composites need to meet certain strength requirements, but there is little research in this field at present. Therefore, this paper studies the compressive strength and flexural strength of crushedrock high-polymer composites through laboratory tests, and analyzes the influences of the mixture ratio, the particle size of crushed rock and the amount of adhesive on the strength of the composites, providing the basis for the theoretical development and engineering application of the composites.

\section{EXPERIMENTAL PART}

\subsection{Raw-material characteristics}

In line with the practical application of the project, we chose limestone as the main crushed rock, mainly including crushed rock I\# particle size no of less than 20 $\mathrm{mm}$ and crushed rock II ${ }^{\#}$ particle size no of less than 40 $\mathrm{mm}$. The particle-size distributions for the two kinds of crushed rock are shown in Figure 1. For crushed rock I\#, about $85 \%$ of the particles are in a range of 5-10 mm, and the remaining particles are basically distributed a the range of 2-5 mm. For crushed rock $\mathrm{II}^{\#}$, about $50 \%$ of the particles are in a range of $20-40 \mathrm{~mm}$, about $47 \%$ of them are in a range of $10-20 \mathrm{~mm}$, while the particles in a range of 5-10 $\mathrm{mm}$ account for only about $3 \%$. In order to analyze the influence of crushed-rock particles on the properties of crushed-rock high-polymer composite, crushed rocks with particle sizes of $20-40 \mathrm{~mm}, 10-20$ $\mathrm{mm}$ and $5-10 \mathrm{~mm}$ were obtained with a screening test determining crushed rock $\mathrm{I}^{\#}$ and crushed rock $\mathrm{II}^{\#}$ as the raw materials for the subsequent test.

Non-foaming polyurethane was chosen as the test high polymer. The high-polymer polyurethane adhesive was made up of component $\mathrm{A}$ and component $\mathrm{B}$ (a mixture ratio of 100:65). Component $A$ was the adhesive and component B was the curing agent, which easily oxidized in air. The mixture of the two should be made quickly, having a uniform structure, and the whole process should be controlled within 2-3 min.
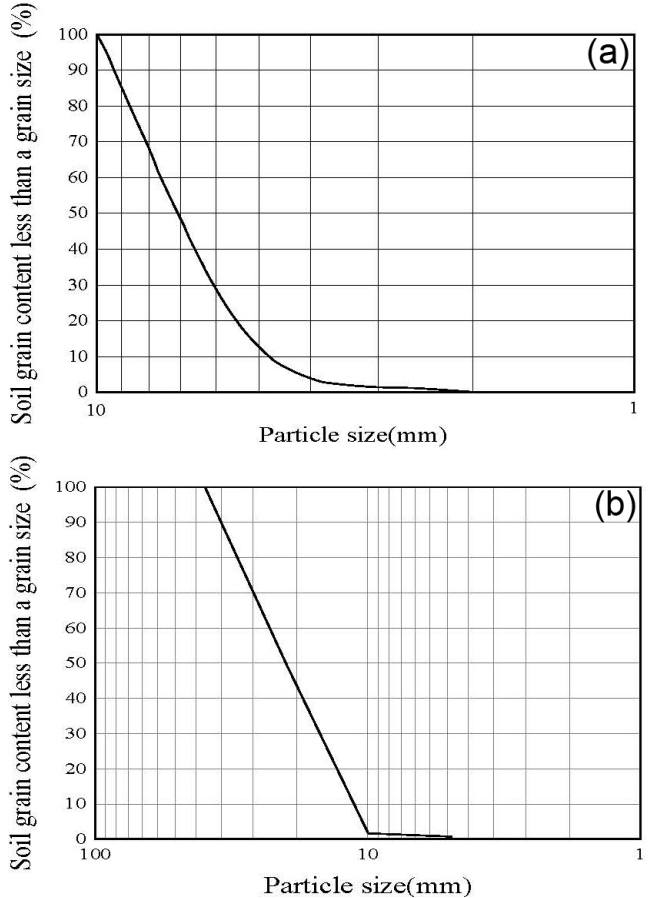

Figure 1: Particle-size distribution curve for crushed rock: a) crushed rock $I^{\#}$, b) crushed rock $\mathrm{II}^{\#}$

\subsection{Test preparation method}

In the stirring process involving the porous materials of the crushed rock and high polymer, the adhesive has a strong viscosity; thus, when the high polymer is wrapped around the surface of the crushed-rock particles, there is a certain viscosity between the particles embedded with each other. Therefore, after pouring the mixture into a trial mold, it cannot be compacted only by self-weight. If no measures are taken to deal with the sample, there will be a large number of holes in the sample, resulting in a large number of defects. Therefore, the porous materials of crushed rock and high polymer require the use of pressure, tamping and other external forces to make the specimen compact. The composite material before and after the forming is shown in Figure 2. In this study, compressive-strength and flexural-strength tests were carried out in accordance with the regulation of Standard Test Method for Mechanical Properties of Normal Concrete. ${ }^{19}$
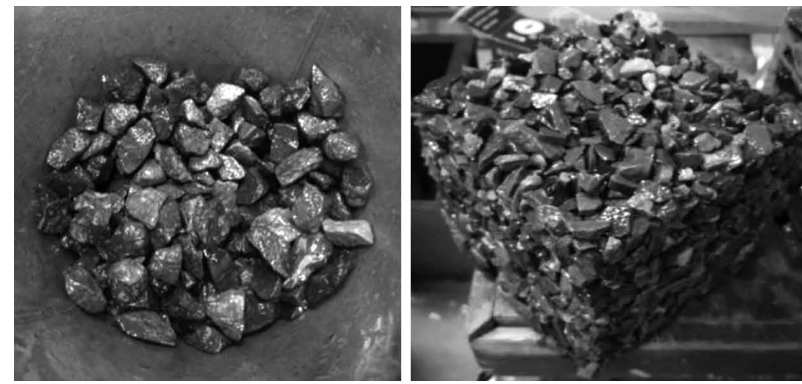

Figure 2: Composite material before and after the forming 


\section{RESULTS AND DISCUSSION}

\subsection{Effect of the material mixture ratio on the compressive strength of composite materials}

Porous materials of crushed rock and high polymer with high-polymer amounts of (2.0, 3.0, 5.0 and 7.0) \% were prepared to obtain various kinds of crushed rock, and cubic compressive specimens were formed $100 \mathrm{~mm}$ $\times 100 \mathrm{~mm} \times 100 \mathrm{~mm}$. After curing at room temperature for $3 \mathrm{~d}$ (days), their compressive strength was measured. The compressive-strength test results are shown in Figure 3. It can be seen that the compressive strength increases gradually with the increase in the amount of polymer adhesive, but the increase range is obviously different. In the early stage, with an increase in the amount of adhesives, the compressive strength increases rapidly. Later, its growth rate gradually slows down. This is mainly due to the strong fluidity of polyurethane adhesives that can only form a thin layer of adhesive cement on the surface of crushed rock. Thus, when the amount of adhesives exceeds a certain level, the excess adhesives flow downward under the action of gravity, filling in the pores and having little effect on the strength growth.

In addition, when the amount of adhesives increases to a certain level, the compressive strength largely depends on the crushing value of the aggregate, so when the amount of adhesives is large, the strength growth tends to be stable. Comparing crushed rocks with different particle sizes, it can be seen that with the same increase in the amount of adhesives, the strength increase is more significant for the porous material of high polymer and crushed rock with a larger particle size. This is mainly because the internal pores of crushed rock are relatively large when the particle size is large and the increased adhesive can effectively fill in the internal pores, thus significantly improving the overall strength of the material.

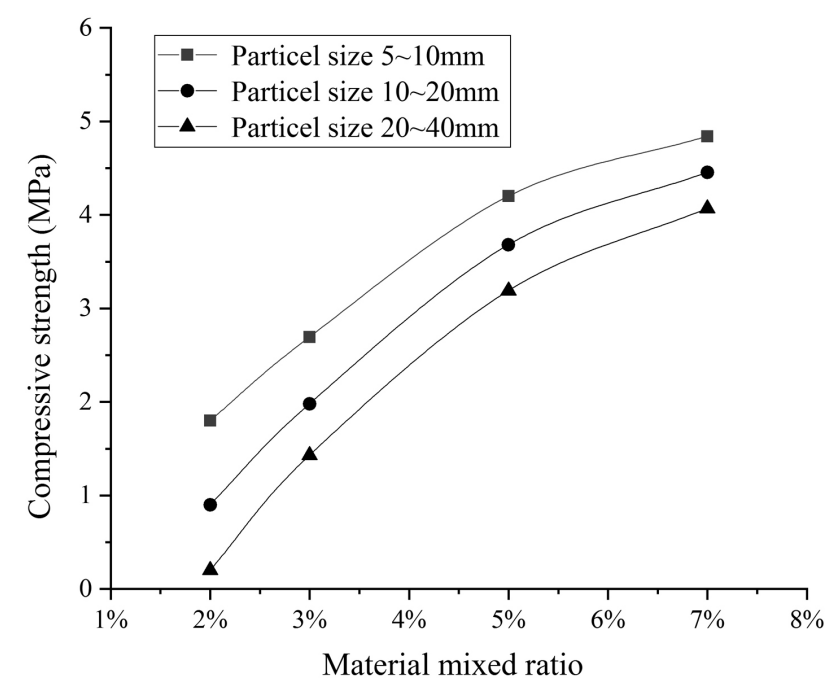

Figure 3: Influence of the material mixture ratio on the compressive strength

\subsection{Effect of the particle size on the compressive strength of composite materials}

The particle size of crushed rock is an important index describing the characteristics of crushed rock. The physical and mechanical properties of crushed rocks with different particle sizes are different, also affecting the strength of porous materials of crushed rock and high polymer. Figure 4 shows the test results for the effect of the particle size of crushed rock on the compressive strength of porous materials of crushed rock and high polymer. It can be seen from the figure that the strength of the composites decreases with an increase in the particle size, regardless of the amount of the high-polymer adhesive in the porous materials. This is mainly because the increase in the particle size of crushed rock leads to an increase in the porosity, and the contact embedding effect between gravel particles weakens. Crushed rock plays an important role in the skeleton of a composite material; so, the overall strength of the composite material is reduced.

It can also be seen from the test results that when the amount of the high-polymer adhesive is large, the decrease in the amplitude of the composite strength caused by the increase in the particle size of crushed rock is lower than when the amount of high polymer is small. This is mainly because when the amount of high polymer is small, it mainly plays the role of wrapping crushed-rock particles and strengthening the bonding among particles; and when the amount of adhesive is large, the surplus high polymer also plays the role of filling in the pores among crushed-rock particles, reducing the impact of the increase of the particle size on the overall strength of the material to a certain extent.

\subsection{Effect of the curing age on the compressive strength of composite materials}

The influence of the curing age on the compressive strength of porous materials made of crushed rock and

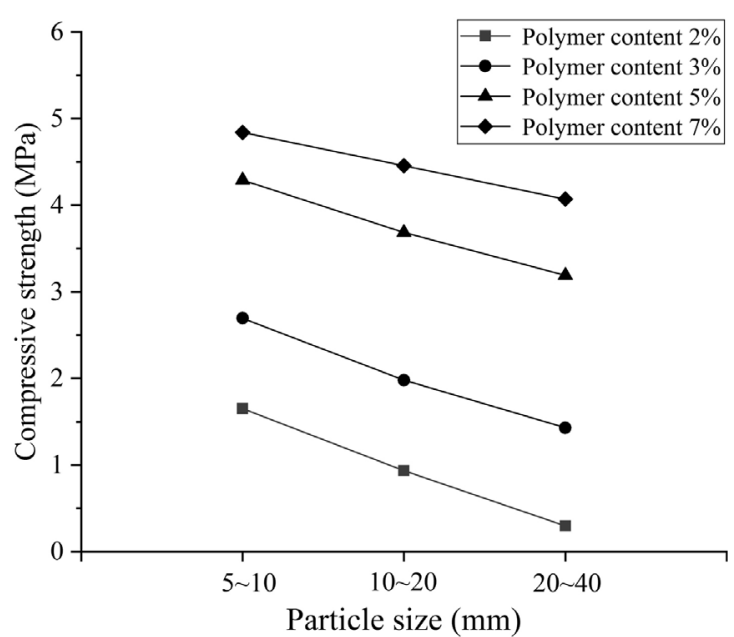

Figure 4: Influence of the particle size $(\mathrm{mm})$ on the compressive strength 
high polymer is analyzed through an experimental study so that the laboratory test can be carried out smoothly, and its findings can also provide guidance to field engineering construction. Taking 5-10 $\mathrm{mm}$ parts of the crushed rock as samples, the mixture ratio of high polymer and crushed rock was 3:100. First, $100 \mathrm{~mm} \times$ $100 \mathrm{~mm} \times 100 \mathrm{~mm}$ cubic compressive specimens were made and then the compressive strength was measured after $3 \mathrm{~h}, 6 \mathrm{~h}, 12 \mathrm{~h}, 1 \mathrm{~d}, 3 \mathrm{~d}, 7 \mathrm{~d}$ and $14 \mathrm{~d}$. Three parallel experiments were conducted for each age and the average value was taken as the final result. The compressive strength after different ages is shown in Figure 5.

The results show that the compressive strength of the porous material including crushed rock and high polymer increases with the increase in the age, increasing rapidly in the early stage. The compressive strength at the age of $1 \mathrm{~d}$ reached $76.1 \%$ of the strength at the age of $14 \mathrm{~d}$; the compressive strength at the age of $3 \mathrm{~d}$ reached $90.7 \%$ of the strength at the age of $14 \mathrm{~d}$; and the compressive strength at the age of $7 \mathrm{~d}$ reached $97.2 \%$ of the strength at the age of $14 \mathrm{~d}$. In the later stage, the compressive strength increased slowly and its increase gradually became gentle. The compressive strength increased by only $(1.7,0.6$ and 0.2$) \mathrm{MPa}$ from (1, 3 and 7) $\mathrm{d}$ to $14 \mathrm{~d}$, respectively. The main reasons are as follows: On the one hand, the polyurethane adhesive itself has a faster hardening speed. Through the flowwrapping effect of the high-polymer material, the polyurethane adhesive forms a thin cemented layer on the surfaces of the crushed-rock particles, and the setting and hardening are faster in air. On the other hand, due to the existence of a large number of pores in the mixture, there are more direct-contact surfaces between the adhesives and air. Under suitable curing conditions, the contact area between the polyurethane adhesives inside a test block and the outside is still very large, thus improving the curing speed of the adhesives and shortening the time of strength formation. Based on the results of different age tests, it was decided to select $3 \mathrm{~d}$ as the

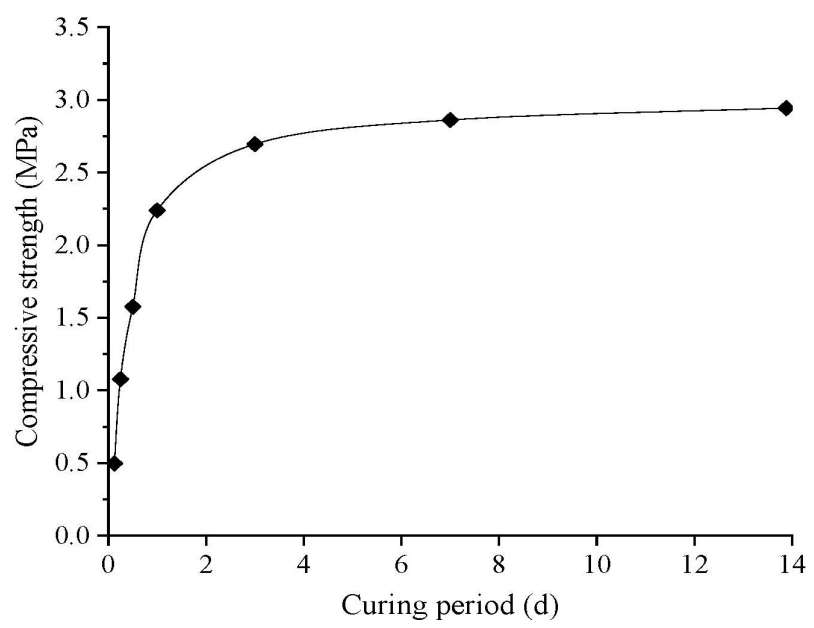

Figure 5: Influence of the curing age on the compressive strength

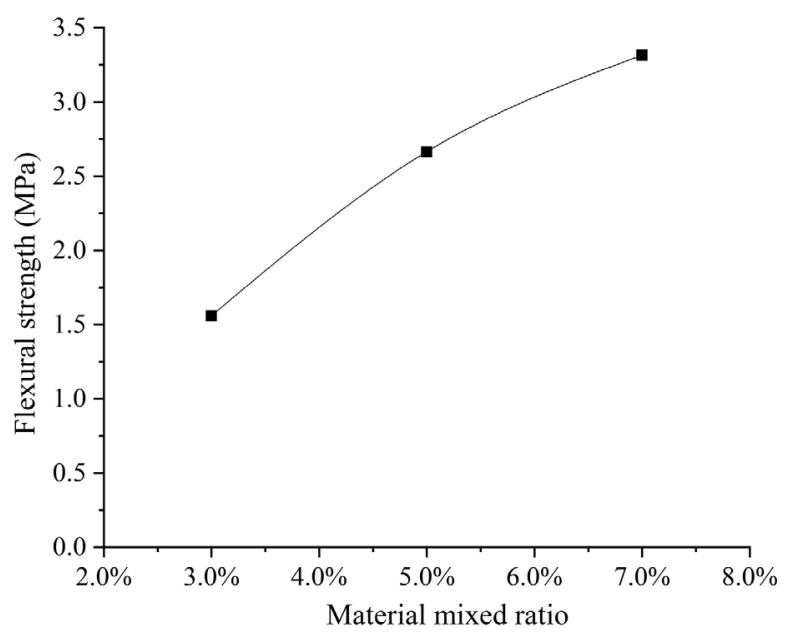

Figure 6: Influence of the material mixture ratio on the flexural strength

curing age for porous materials of crushed rock and high polymer.

\subsection{Effect of the material mixture ratio on the flexural strength of composite materials}

Figure 6 shows the effect of the material mixture ratio on the flexural strength of porous materials of crushed rock and high polymer (the particle size of the crushed rock is $5-10 \mathrm{~mm}$ ). For the crushed rock with a single size, the flexural strength gradually increases with the increase in the amount of adhesives. Observing the damaged sections of flexural specimens, it can be seen that most of the damaged sections of the porous material occur at the junctions of crushed rock and high polymer; and the reason are clear: The adhesive property between the crushed-rock aggregates is insufficient. Some of the damaged sections are caused by a direct fracture of the crushed rock, that is, the quality of the aggregates is not high. Therefore, in order to improve the flexural strength, we can use two approaches: On the one hand, the adhesive ability should be improved, and the amount of adhesives should be increased. On the other hand, the quality of the crushed rock should be improved, and the crushed rock with a higher quality and strong shear resistance should be selected.

\subsection{Effect of the particle size of crushed rock on the flexural strength of composite materials}

Figure 7 shows the effect of the particle size of crushed rock on the flexural strength of porous materials of crushed rock and high polymer (the mixture ratio is 100:3). The results of the flexural-strength test show that the flexural strength decreases with the increase in the particle size when the amount of adhesive is fixed for a single-type crushed rock. The reason for this is that a small-sized crushed rock makes the contact point between the mixtures larger, which is equal to increasing 


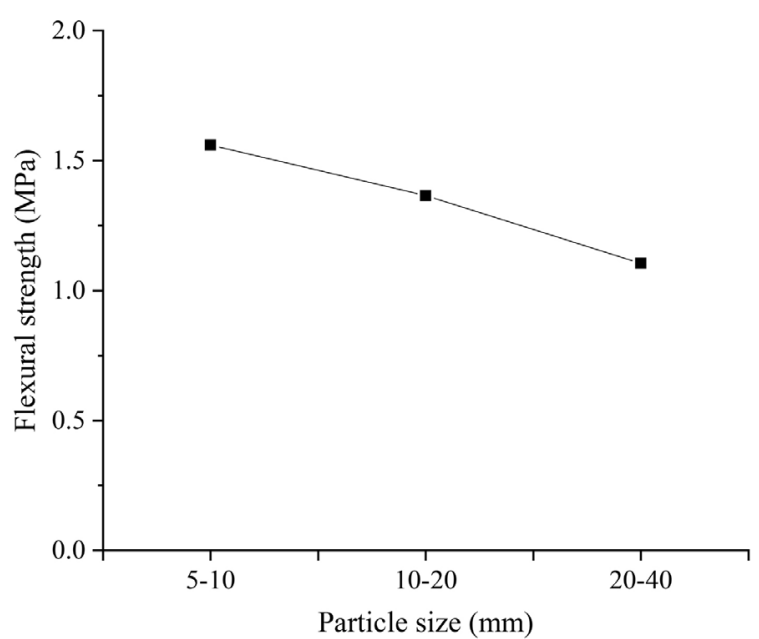

Figure 7: Influence of the particle size of crushed rock on the flexural strength

the effective bearing area. Thus, the smaller the particle size, the greater is the flexural strength.

\subsection{Strength formation and failure characteristics of composite materials}

Based on the above compressive and flexural test results, it can be seen that the composite of crushed rock and high polymer is a kind of a macroporous crushedrock mixture. It usually does not contain fine aggregates and fillers, but it is prepared by mixing single-particle-size crushed rock with a polyurethane adhesive. Its strength depends mainly on the mutual embedment (a point-to-point contact) between the crushed-rock aggregates and the bonding strength of polymer adhesives. Polyurethane adhesives are easy to oxidize and consolidate when exposed to air. After hardening, the aggregate is cemented into a whole, and the strength is formed accordingly. Therefore, the strength-formation mechanism of a crushed-rock high-polymer mixture is different from that of conventional asphalt or cement binder, leading to its particular protective performance.

According to the damaged sections of compressive specimens, the compressive strength of the crushed-rock high-polymer mixture is basically destroyed at the point-contact position, and there are two main kinds of damage: 1. The bond interface is damaged. 2. The crushed rock is broken. Although the generally measured compressive strength of the mixture is not high, the pressure on its internal contact point is very large. From the damaged sections of the specimens, it can be seen that the flexural damage of the crushed-rock high-polymer mixture is mainly due to the lack of adhesive property at the contact point of the mixture and the breaking of some of the crushed rock. This shows that the flexural strength of the crushed-rock high-polymer mixture is closely related to the amount of adhesive and the ability of the aggregate to resist breaking.
Observing the development of cracks, we can see the damage process of the crushed-rock high-polymer mixture: there are many pores in the mixture, making the point-contact state between the aggregates dominant. This kind of contact state tells us that the internal stress state of the mixture is extremely complex, easily producing a stress-concentration failure while there are already a few cracks. When the pressure exceeds a certain limit, there is an obvious stress redistribution in the mixture and with a further increase in the stress, the cracks further expand until the bonding surface between the crushed-rock aggregates or between the crushed rock and the adhesive is completely broken. Then the cracks and pores in the mixture are connected, eventually leading to a structural damage of the mixture.

\section{CONCLUSIONS}

Through laboratory tests, the strength characteristics of a composite including crushed rock and high polymer are studied, the influences of the material mixture ratio and the particle size of crushed rock are analyzed, and the strength-formation mechanism of the composite is explained. According to the test results, the main conclusions are as follows:

(1) The strength of crushed-rock high-polymer porous materials mainly comes from the oxidative consolidation of high-polymer adhesives and mutual embedment of crushed-rock aggregates; the strength increases rapidly in the early stage and gradually becomes stable in the later stage. The compressive strength after $3 \mathrm{~d}$ reaches about $90.7 \%$ of the compressive strength after $14 \mathrm{~d}$.

(2) The test results show that the compressive strength of the porous materials of crushed rock and high polymer is less than $5 \mathrm{MPa}$ and the flexural strength is less than 3.5 MPa. The amount of adhesive, particle size of crushed rock, curing age and other factors have an impact on its strength; the amount of adhesive and the particle size of crushed rock have a significant impact on the strength.

(3) According to the strength test results for the porous materials of crushed rock and high polymer, compressive damage and flexural damage are mainly shown in the damage of the bond of the particle interface, and some are due to the fragmentation of the crushed rock.

(4) In order to improve the strength of the porous materials of crushed rock and high polymer, the following three measures can be considered: the first is to improve the interfacial bond strength between crushed rock and high-polymer adhesive; the second is to increase the total area of aggregate contact points; the third is to select a high-quality crushed rock. 


\section{J. ZHANG: EXPERIMENTAL STUDY ON STRENGTH CHARACTERISTICS OF CRUSHED-ROCK HIGH-POLYMER ...}

\section{Acknowledgments}

The authors are grateful for the financial support from the National Natural Science Foundation of China (No. 51709145 and No. 516782921) and the Scientific Research Foundation of Nanjing Institute of Technology (YKJ201727).

\section{REFERENCES}

${ }^{1}$ J. Carlos, A. Huerta, H. Oumeraci, Soil stability analysis for waveinduced momentary liquefaction beneath porous bonded revetments, Coastal Engineering, 138 (2018), 22-35, doi:10.1016/j.coastaleng. 2018.04.003

${ }^{2}$ Y. Li, J. Simunek, Z. Zhang, Water flow and nitrate transport through a lakeshore with different revetment materials, Journal of Hydrology, 520 (2015), 123-133, doi:10.1016/j.jhydrol.2014.11.045

${ }^{3}$ X. S. He, Y. Pang, Y. H. Lu, Investigation on water purifying revetment technology, Journal of Hydraulic Engineering, 39 (2008) 6, 659-666, doi:10.3321/j.issn:0559-9350.2008.06.004

${ }^{4}$ K. Gunaydin, M. S. Kabdasli, Protection of shoreline by using partial revetment structure under regular and irregular waves, Journal of Coastal Research, 22 (2006), 1349-1359, doi:10.2112/03-0080.1

${ }^{5}$ K. Gunaydın, M. S. Kabdasli, Static stability of submerged partial revetment structures under regular and irregular waves, Ocean Engineering, 30 (2003) 6, 761-777, doi:10.1016/S0029-8018(02) 00059-8

${ }^{6}$ L. Li, Y. Pan, F. Amini, Erosion resistance of HPTRM strengthened levee from combined wave and surge overtopping, Geotechnical and Geological Engineering, 32 (2014) 4, 847-857, doi:10.2112/ JCOASTRES-D-12-00010.1.

${ }^{7}$ S. Yuan, L. Li, F. Amini, Numerical study of turbulence and erosion of an HPTRM-strengthened levee under combined storm surge overflow and wave overtopping, Journal of Coastal Research, 30 (2014) 1, 142-157, doi:10.2112/JCOASTRES-D-12-00250.1

${ }^{8}$ Y. Pan, L. Li, F. Amini, Influence of three levee-strengthening systems on overtopping hydraulic parameters and hydraulic equivalency analysis between steady and intermittent overtopping, Journal of
Waterway, Port, Coastal and Ocean Engineering, 139 (2012) 4, 256-266, doi:10.1061/(ASCE)WW.1943-5460.0000179

${ }^{9}$ Y. Pan, L. Li, F. Amini, Full-scale HPTRM-strengthened levee testing under combined wave and surge overtopping conditions: Overtopping hydraulics, shear stress, and erosion analysis, Journal of Coastal Research, 29 (2012) 1, 182-200, doi:10.2112/JCOASTRESD-12-00010.1

${ }^{10}$ M. H. Li, S. Khanna, Aging of rolled erosion control products for channel erosion control, Geosynthetics International, 15 (2008) 4, 224-231, doi:10.1680/gein.2008.15.4.224

${ }^{11}$ H. Zhong, B. Zhang, Y. Wang, Research on elastocoast revetment wave model test, Applied Mechanics and Materials, 353-356 (2013), 2693-2698, doi:10.4028/www.scientific.net/AMM.353-356.2693

${ }^{12}$ H. J. Verhagen, Elastomeric revetments: a new way of coastal protection, Second forum on Delta \& Costal Development, Amsterdam, 2009

${ }^{13}$ M. Liu, F. Niu, W. Ma, Experimental investigation on the enhanced cooling performance of a new crushed rock revetment embankment in warm permafrost regions, Applied Thermal Engineering, 120 (2017), 121-129, doi:10.1016/j.applthermaleng.2017.03.118

${ }^{14} \mathrm{M}$. Soldinger, Transport velocity of a crushed rock material bed on a screen, Minerals Engineering, 15 (2002) 1, 7-17, doi:10.1016/ S0892-6875(01)00192-3

${ }^{15}$ J. Qian, Q. Yu, L. Guo, Experimental study on convection characteristics of crushed-rock layer, Canadian Geotechnical Journal, 50 (2013) 8, doi:10.1139/cgj-2011-0201

${ }^{16} \mathrm{~S}$. Chakrabarti, J. Kodikara, Direct tensile failure of cementitiously stabilized crushed rock materials, Canadian Geotechnical Journal, 44 (2007) 2, 231-240, doi:10.1139/cgj-2015-0245

${ }^{17}$ L. Borgesson, L. E. Johannesson, D. Gunnarsson, Influence of soil structure heterogeneities on the behaviour of backfill materials based on mixtures of bentonite and crushed rock, Applied Clay Science, 23 (2003) 1, 121-131, doi:10.1016/S0169-1317(03)00094-2

${ }^{18}$ D. Ma, X. X. Miao, G. H. Jiang, An experimental investigation of permeability measurement of water flow in crushed rock, Transport in Porous Media, 105 (2014) 3, 571-595, doi:10.1007/s11242014-0385-5

${ }^{19}$ GB/T 50081:2002 Standard Test Method for Mechanical Properties of Normal Concrete, Ministry of Construction, China 